\title{
The Portrayal of Tourette Syndrome in Film and Television
}

\author{
Samantha Calder-Sprackman, Stephanie Sutherland, Asif Doja
}

\begin{abstract}
Objective: To determine the representation of Tourette Syndrome (TS) in fictional movies and television programs by investigating recurrent themes and depictions. Background: Television and film can be a source of information and misinformation about medical disorders. Tourette Syndrome has received attention in the popular media, but no studies have been done on the accuracy of the depiction of the disorder. Methods: International internet movie databases were searched using the terms "Tourette's", "Tourette's Syndrome", and "tics" to generate all movies, shorts, and television programs featuring a character or scene with TS or a person imitating TS. Using a grounded theory approach, we identified the types of characters, tics, and co-morbidities depicted as well as the overall representation of TS. Results: Thirty-seven television programs and films were reviewed dating from 1976 to 2010. Fictional movies and television shows gave overall misrepresentations of TS. Coprolalia was overrepresented as a tic manifestation, characters were depicted having autism spectrum disorder symptoms rather than TS, and physicians were portrayed as unsympathetic and only focusing on medical therapies. School and family relationships were frequently depicted as being negatively impacted by TS, leading to poor quality of life. Conclusions: Film and television are easily accessible resources for patients and the public that may influence their beliefs about TS. Physicians should be aware that TS is often inaccurately represented in television programs and film and acknowledge misrepresentations in order to counsel patients accordingly.
\end{abstract}

RÉSUMÉ: Représentation du syndrome de la Tourette au cinéma et à la télévision. Objectif : Le but de l'étude était de déterminer comment est représenté le syndrome de la Tourette (ST) chez les personnages fictifs du cinéma et dans les programmes de télévision en étudiant les thèmes et les descriptions récurrentes. Contexte : La télévision et le cinéma peuvent être une source d'informations et de renseignements erronés concernant les problèmes médicaux. Le syndrome de la Tourette a reçu de l'attention dans les médias populaires, cependant aucune étude n'a porté sur l'exactitude de la représentation de cette maladie. Méthode : Nous avons effectué une recherche dans les bases de données internationales de films, accessibles par Internet, en utilisant les mots-clés « Tourette's », « Tourette's Syndrome » et « tics » afin d'identifier tous les films, les courts métrages et les programmes de télévision comportant un personnage atteint de ST ou une personne imitant le ST. Une approche théorique à base empirique nous a permis d'identifier les types de personnages, les tics et les comorbidités représentées ainsi que la représentation globale du ST. Résultats : Trente-sept programmes de télévision et films datant de 1976 à 2010 ont été examinés. La représentation du ST était globalement erronée dans les intrigues au cinéma et les programmes de télévision. La coprolalie était surreprésentée en tant que tic, les personnages étaient décrits comme présentant des symptômes appartenant aux troubles du spectre autistique plutôt qu'au ST et les médecins étaient représentés comme antipathiques et n'ayant recours qu'aux traitements médicaux. Les relations à l'école et au sein de la famille étaient fréquemment décrites comme étant altérées par le ST, entraînant ainsi une piètre qualité de vie. Conclusions : Le cinéma et la télévision sont des ressources facilement accessibles pour les patients et le public et susceptibles d'influencer leurs croyances au sujet du ST. Les médecins devraient être conscients que le ST est souvent représenté de façon erronée à la télévision et au cinéma, ce qu'ils pourront signaler aux patients et qui leur permettra de mieux les conseiller.

Can J Neurol Sci. 2014; 41:226-232

Gilles de la Tourette's syndrome (TS) is a neuropsychiatric disorder characterized by recurrent motor and vocal tics for at least one year ${ }^{1}$. Tourette's syndrome has a prevalence of $0.4 \%$ to $3.8 \%$ in children aged 5 to 18 years $^{2}$, with peak severity between the ages of 8 to $12^{3}$. Common co-morbidities include attention deficit hyperactivity disorder (ADHD) ${ }^{4}$, learning disabilities ${ }^{5}$, and obsessive compulsive disorder (OCD) ${ }^{6}$. The etiology of TS is unknown, and as such, its symptoms are often misdiagnosed and misunderstood by the lay public ${ }^{7}$.

This lack of understanding may be why peers rate individuals with tics lower in social acceptability ${ }^{8}$. Stokes and colleagues found that school-aged children with TS are rated significantly lower in popularity than their peers and are viewed as more aggressive and withdrawn ${ }^{9}$. Nearly half of TS patients suffer from social and educational dysfunction ${ }^{10}$. Due to the pervasive nature of television and movies, fictional depictions of TS in popular media may influence society's behaviours, values, and attitudes towards the disorder, which could ultimately influence the self-esteem of those with TS, as well as their family and school relationships.

From the Faculty of Medicine (SCS, SS, AD), University of Ottawa; Division of Neurology (AD), Department of Pediatrics, Children's Hospital of Eastern Ontario, Ottawa, Ontario, Canada.

Received November 8, 2012. Final Revisions Submitted October 17, 2013. Correspondence to: Asif Doja, Department of Pediatrics, Children's Hospital of Eastern Ontario, 401 Smyth Road, Ottawa, Ontario, K1H 8L1, Canada.

Email: adoja@cheo.on.ca. 
Despite TS having received popular media attention there has yet to be a study investigating the portrayal of TS in film and television. The aim of the study was to investigate recurrent depictions of TS to indentify major themes of its portrayal in fictional television programs and films.

\section{Methods}

\section{Search Strategy}

International internet movie databases were searched using the key words "Tourette's", "Tourette's Syndrome," and "Tics". All movies, shorts, and television programs featuring characters or scenes with TS or a person imitating TS were sought. The searches were conducted using IMdb.com, allmovie.com, reel.com, rottentomatoes.com, foreignfilms.com, The Chinese Movie database (www.dianying.com), the Asian Movie database (asiandb.com), and the Bollywood Movie Database (www.bollywood.de). Similar search strategies have been adopted in other studies that investigated the cinematic portrayal of neurological conditions ${ }^{11-14}$. Wikipedia was also searched using the key term "Tourette's Syndrome"; movies and television programs identified in the "Film and TV section" from the Social and Cultural Aspects of Tourette's Syndrome page (http://en.wikipedia.org/wiki/Sociological_and_cultural_aspects

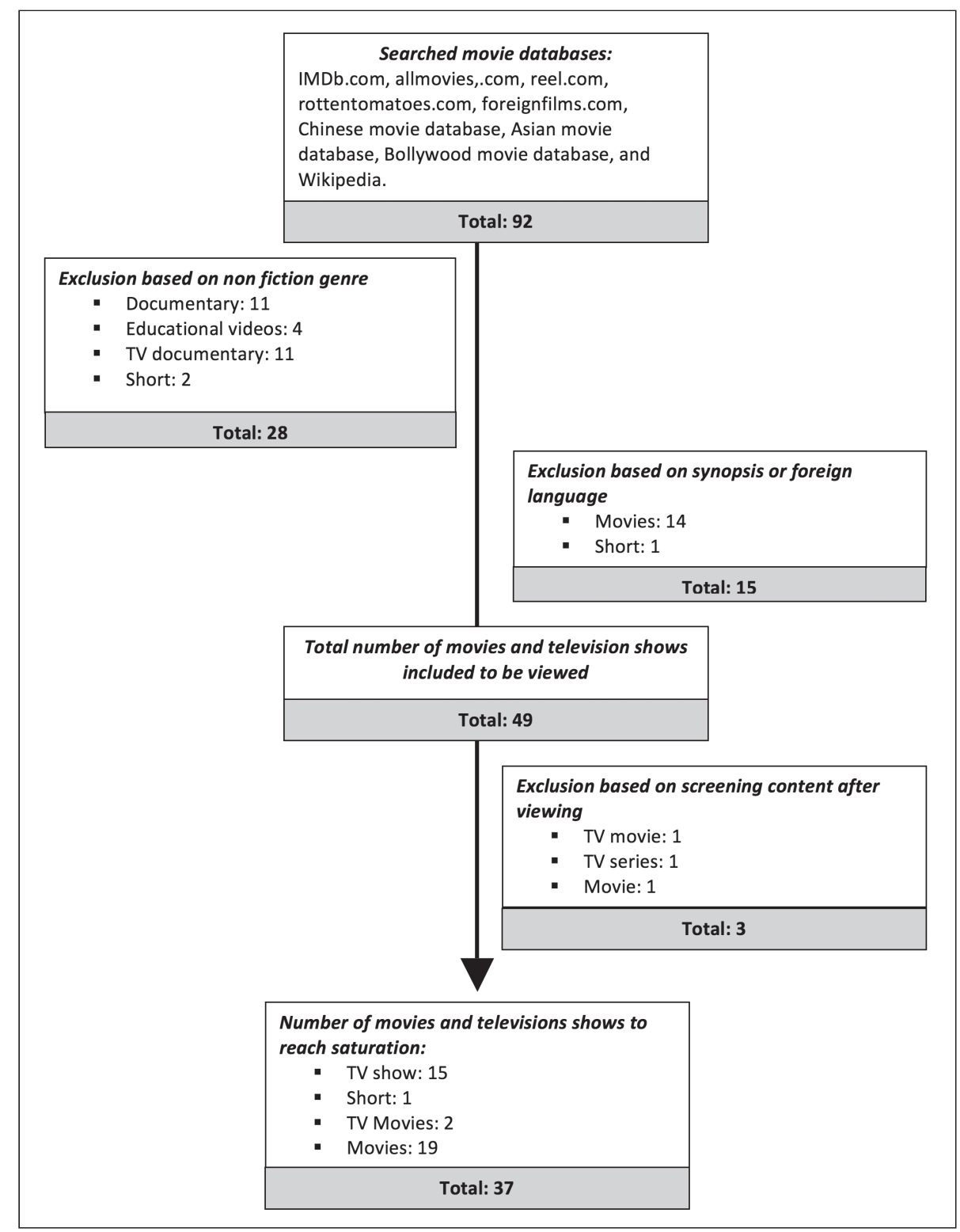

Figure 1: Search Strategy. Outline of search strategy for retrieving and viewing films and television shows. 
Table: Characteristics of persons portraying or imitating Tourette syndrome

\begin{tabular}{l|l|l|l|l}
\hline Characteristics & Films & $\begin{array}{l}\text { Television } \\
\text { Shows }\end{array}$ & Shorts & Example \\
\hline Character has TS & 16 & 11 & 1 & N/A \\
\hline Imitating TS & 8 & 6 & 0 & $\begin{array}{l}\text { In South Park, }{ }^{16} \text { Cartmen pretends he has TS so that he has an excuse to swear } \\
\text { whenever he wishes. }\end{array}$ \\
\hline $\begin{array}{l}\text { Portrayed with an } \\
\text { eccentric appearance }\end{array}$ & 6 & 0 & 1 & $\begin{array}{l}\text { In Dirty Filthy Love, }{ }^{17} \text { Mark wears dirty clothes, grows a matted beard and has } \\
\text { unkempt hair. }\end{array}$ \\
\hline $\begin{array}{l}\text { Negative family } \\
\text { dynamics seen }\end{array}$ & 5 & 3 & 0 & $\begin{array}{l}\text { In Maze, }{ }^{18} \text { Lyle's father washes out his mouth with soap following an episode of } \\
\text { coprolalia to teach him not to swear again. }\end{array}$ \\
\hline $\begin{array}{l}\text { Negative impact on } \\
\text { school seen }\end{array}$ & 4 & 4 & $\begin{array}{l}\text { In an episode of The Practice, } \\
\text { disruptive in the classroom because of her tics. }\end{array}$ \\
\hline $\begin{array}{l}\text { Negative impact on } \\
\text { interpersonal } \\
\text { relationships }\end{array}$ & 8 & 7 & 1 & $\begin{array}{l}\text { In The Tic Code, }{ }^{20} \text { Tyronne's insecurities surrounding his tics are so strong that he } \\
\text { refuses to have conversations with his romantic partner about his symptoms, which } \\
\text { eventually leads to a break up. }\end{array}$ \\
\hline
\end{tabular}

Summary of characteristics of persons in films, television and shorts portraying or imitating Tourette Syndrome

_of_Tourette_syndrome) were included. Films and television programs were sought until no new names were generated from any source. We excluded television and video documentaries, as the purpose of the study was to review fictional representations. Movies and television programs that were clearly irrelevant were also excluded (e.g. a film making reference to a character "being the political equivalent of TS"). Films in foreign languages that were not available or subtitled or dubbed in English were not reviewed.

\section{Review of Movies}

The same reviewer (SCS) viewed all movies, shorts, and television programs identified in the search. A second reviewer (AD) viewed movies and television shows at initiation of the study until coding reliability was ensured $(n=3)$. We reviewed movies and television shows available on VHS or DVD. If a movie or television program could not be viewed in its entirety, youtube.com was searched for the clip of the film or episode that included TS. Some films included using the search strategy did not fulfill the criteria of having a character or scene with TS or imitating a person with TS, and therefore were excluded after viewing.

Movies and television shows were reviewed using grounded theory, a common systematic methodology used in social science research. Grounded theory generates theoretical explanation for sociological phenomena from a set of data without any predetermined hypothesis. ${ }^{15}$ During viewings, notes were taken using ten minute time markers to ensure a minimum consistent amount of notes were taken throughout the entire film. All data was then reviewed and coded. During coding, the grounded theory approach allowed for emergent themes surrounding demographics of characters with TS, vocal and motor tics seen, physician involvement with the patient, and characters' social and romantic relationships were identified and coded as such. Emotions that the portrayal of TS was meant to evoke were also considered. Movies and television shows were viewed until saturation of themes was reached. For example, viewing continued until no new themes were found in the movies and television shows. At this point, the authors were confident that enough movies and television shows were viewed.

\section{RESUlts AND Discussion}

\section{Cinematic Details}

Ninety-two films and television shows were generated using the search strategy (Figure 1). Forty-nine films and television shows were eligible for inclusion into the study. Saturation of themes was reached after viewing 37 films and television shows (15 television show episodes, 1 short, 2 made-for-television movies, and 19 fictional movies) (For a full list of all film and television shows see Appendix 1). We found the largest number of television shows and movies with characters who had TS or were imitating TS after $1990(2.7 \%$ before $1980 ; 8 \cdot 1 \%$ from 1980 through $1989 ; 35 \cdot 1 \%$ from 1990 through $1999 ; 51 \cdot 4 \%$ from 2000 through 2009 ; and $2.7 \%$ after 2010). The majority of shows and films that featured TS were comedies $(n=16)$ and dramas $(n=16)$; one romance, and four action movies also depicted the disorder. Characteristics of characters having TS or imitating TS are summarized in Table $1^{16-20}$.

\section{Depiction of $T S$}

Characters who suffered from TS were featured in $66.6 \%$ of the films and television shows. The remainder of the films and television programs reviewed had 14 characters imitating or impersonating a person with TS. The majority of characters with TS or imitating TS were male $(74 \%)$, which is in keeping with what is clinically expected as males are four times more likely than females to have $\mathrm{TS}^{21}$.

A variety of motor and vocal tics were depicted in the films (Figures 2 and 3); neck bending was the most common motor tic and the most common vocal tic was coprolalia. Of the characters imitating TS, 73\% (11/15) exhibited coprolalia, giving a misleading impression that coprolalia is the most common symptom of TS. In reality, coprolalia has a prevalence of $8.5 \%$ 


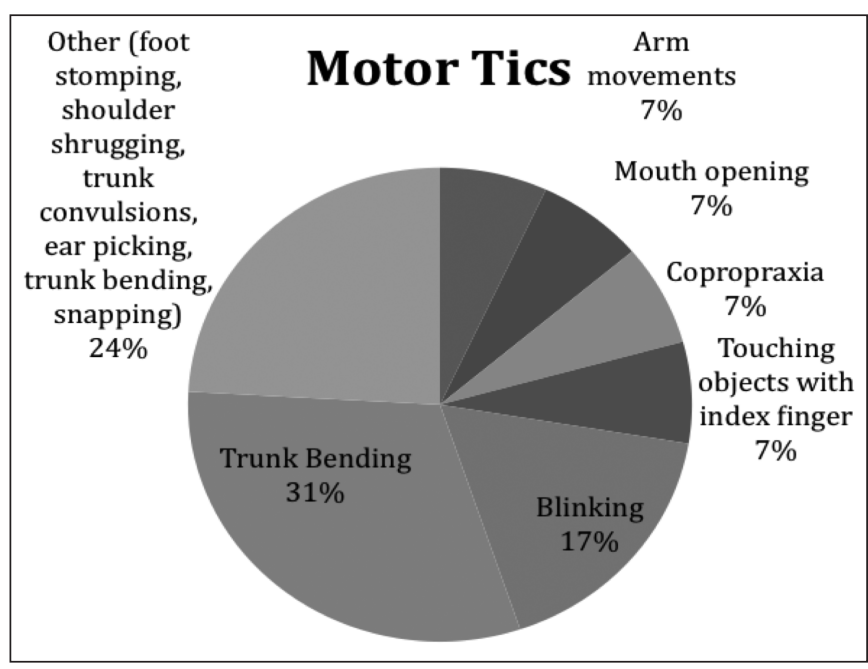

Figure 2: Motor Tics. The frequency of motor tics in characters portraying TS.

to $50 \%$ in $\mathrm{TS}$ patients ${ }^{1,22}$, but remains a widely recognized clinical feature of TS by laypersons. Furthermore, the actors in most television and films reviewed did not adequately portray coprolalia but rather demonstrated more typical swearing in the context of a sentence. The use of coprolalia for comedic effect falsely emphasizes this as a key symptom of TS, giving TS the reputation of "the cursing disease" in popular media 23 .

\section{Film Genres and Portrayal of TS}

Despite the fact that most characters with TS were portrayed as well groomed with normal appearance, many were also shown to have an eccentric look. In reality, children with TS do not appear physically different from others and are similar to controls on most measures of externalizing behavior and social adaptation $^{23}$. Although the visual impact of tics can draw public attention, making characters dress eccentrically in films is an inaccurate representation of TS and may promote stigmatization, which can contribute to a lack of public acceptance for this population $^{23}$.

Although tics were glorified in many of the films and television programs, general information regarding tics was accurate. Tics were most commonly compared to an uncontrollable urge similar to a sneeze (South Park, ${ }^{16}$ Harvie Krumpet, ${ }^{24}$ First of the Class, ${ }^{25}$ Deuce Bigalow: Male Gigalo, ${ }^{26}$ The Simpsons, ${ }^{27}$ The Big White, ${ }^{28}$ Dirty Filthy Love, ${ }^{17}$ Ally McBeal, ${ }^{29} 7$ th Heaven, ${ }^{30}$ L.A. Law, ${ }^{31}$ and Nurse Jackie ${ }^{32}$ ). Tics were also shown to be suppressible (The Tic Code, ${ }^{20}$ Touched by an Angel ${ }^{33}$ ) and worse in stressful situations (The Tic Code, ${ }^{20}$ Maze ${ }^{18}$ Dirty Filthy Love ${ }^{17}$ ).

In comedic films, TS was usually imitated by characters in the form of coprolalia. The diagnosis of TS was used to excuse inappropriate swearing and create a comedic effect (South Park, ${ }^{16}$ Jumping Jack Flash, ${ }^{34} 500$ Days of Summer, ${ }^{35}$ Wedding Crashers, ${ }^{36}$ The Wedding Singer, ${ }^{37}$ The Simpsons ${ }^{27}$ ).

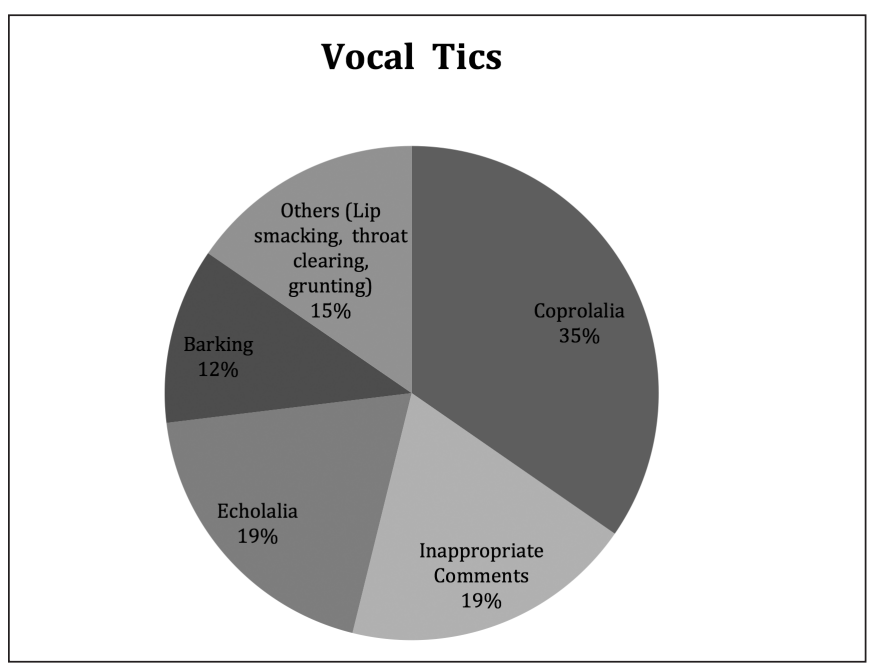

Figure 3: Vocal tics. The frequency of vocal tics in characters portraying TS

\section{Depiction of the Etiology, Diagnosis, and Treatment of TS}

The etiology of TS in most films seemed to be idiopathic. Diagnosing physicians provide some inaccurate information to patients. Doctors often showed little understanding of the syndrome, provided medically inaccurate information, and demonstrated minimal compassion for patients with TS and their families. Moreover, medical treatment of the disorder was always presented negatively. This cinematic depiction of physicians is consistent with studies showing that physicians are often shown as egotistical and uncaring in fictional films, like "mad scientists" who value science more than patient welfare ${ }^{13}$.

Treatment of TS was not addressed in detail in any film or television program reviewed. Any medication suggested for symptom management was always spoken about negatively. Four programs (one movie and three television shows) mentioned the medication haloperidol. Other medications briefly mentioned include clonidine (L.A. Law $w^{31}$ ) and Prozac (Harvie Krumpet $^{24}$ ); however, no explanation is given regarding the reason they are prescribed, their efficacy, or their side effects. Doctors were accused of simply trying to fix TS through medicating their patients without taking into consideration side effects and challenges that the medications may create (Phoebe in Wonderland $^{38}$ ).

\section{Social Implications of TS: Family relationships, School} Environment, and Friendships

\section{Negative Family Dynamics}

A common feature of the television programs and movies reviewed was the notion of a challenging family dynamic for the child with TS (Maze, ${ }^{18}$ Phoebe in Wonderland, ${ }^{38}$ The Tic Code, ${ }^{20}$ South Park ${ }^{16}$ ). Family stress was most often shown to be driven by the lack of family support and understanding for their child's aesthetically disruptive movements. Conflicts occurred when parents were unable to agree on if they should be concerned about the tics (Phoebe in Wonderland,,$^{38}$ Maze, ${ }^{18} 7$ th Heaven, ${ }^{30}$ 
The Tic $\left.\operatorname{Code}^{20}\right)$. Moreover, siblings of children with TS were also shown to be impacted by the syndrome (Phoebe in Wonderland, ${ }^{38}$ Touched by an Angel ${ }^{33}$ ). There is a lack of public acceptance of inappropriate behaviors in particular spaces at improper times and patients with TS can be accused of "doing it on purpose" $7,8,23$. Although many patients with TS find close family and select friends understand the behaviours, it can be a problem to appear out of control in our society where self-control is valued and expected ${ }^{10,23}$.

\section{Challenging School Environment}

An unwelcoming school environment, including bullying, for individuals with TS was another common finding. They are shown to be unpopular, typically having a hard time forming friendships $\left(7\right.$ th Heaven $\left.^{30}\right)$. Children with TS expressed the desire to be treated like everyone else in the school environment (Front of the Class, ${ }^{25}$ South Park ${ }^{16}$ ), but this appears to seldom occur in movies and television. In reality, at school and in other public places, patients with TS find that each twitch or noise they make is an opportunity for others to make a comment on their behavior $^{8,10,23}$. This attention forces individuals with TS to feel they need to seek privacy to express their tics freely and escape the notice of others and their stigmatizing reactions ${ }^{9,10,23}$.

\section{Romantic Relationships}

Several films depicted romantic relationships as challenging for patients with TS. Characters developed romantic relationships with partners who express not caring about or noticing the tics (The Big White, ${ }^{28}$ Maze, ${ }^{18}$ The Tic Code ${ }^{20}$ L.A. Law, ${ }^{31}$ Dirty Filthy Love ${ }^{17}$ ). However, despite finding loving partners who accepted them, characters with TS are shown to be insecure about their tics and push romance away (Maze, ${ }^{18}$ The Tic $\left.\operatorname{Code}^{20}\right)$. Overall, films and television programs imply that it is difficult for characters with TS to find love because of insecurities about their tics. (L.A. Law, ${ }^{31}$ Maze, ${ }^{18}$ The Tic $\left.\operatorname{Code}^{20}\right)$.

Overall, there was a disproportionate representation of negative school, social, and family relationships. Nearly all television programs and movies reviewed demonstrated challenges in at least one of these areas. No films showed positive school experiences for children with TS. Although it is common for children to face challenges in the school and social environments, overrepresentation of negative social experiences for patients with TS may give patients the impression that TS will undoubtedly negatively affect these areas of their lives. A study that investigated the quality of life of patients with TS found that despite the fact that patients had challenges making and developing friendships and relationships, $71 \%$ of them found their families supportive and/or enjoyed their marriage ${ }^{39}$.

Furthermore, it has also been shown that the impact of TS symptoms in adulthood is relatively modest and that most are able to cope with family and medical support ${ }^{40}$.

\section{Portrayal of Other Psychiatric and Neurologic Diseases}

Although neurological diseases have been featured in many motion pictures, few studies have examined their representation. Two studies investigating seizures in movies showed that cinematic depictions of seizure disorders were over- exaggerated ${ }^{11}$ and that first aid treatment was inappropriate in the majority of cases ${ }^{12}$. A study on the portrayal of coma also concluded that misrepresentations of coma and awakening occurred in movies, subsequently impacting public perception of coma ${ }^{13}$.

\section{Limitations}

There were several limitations to our study. First, it is possible that our subjective analysis of the television program and movie portrayals may not be shared by the general viewing public. Second, although all efforts were made in the design of the search strategy to maximize videos and television programs that were viewed, there were still some videos that could not be obtained, particularly foreign films. These omissions reflect the bias of only looking at English language depictions. Therefore, we cannot claim that this is a complete assessment of all representations of TS in fictional movies and television programs. However, many reviewed movies and television episodes were current, popular, widely viewed and would have likely been seen by the general public. As such, the viewing public is likely to be exposed to film and television shows with similar portrayals of TS as those found in this study.

\section{Conclusions}

This is the first study to look at the portrayal of TS in fictional movies and television programs. The findings of our study are consistent with other studies that have misrepresented medical conditions in popular media ${ }^{41}$. Given that the primary goal of a movie is to entertain, it is understandable why screenwriters exaggerate diseases to create dramatic or comedic effects. However it has been argued that producers and screenwriters should have a responsibility to be more accurate in their representation of medical conditions ${ }^{41}$. Until such a change occurs, however, physicians must continue to recognize and acknowledge misrepresentations in popular media and counsel patients accordingly.

When patients are given a new diagnosis of TS, they have few sources from which they can gather and learn information. Since information in the popular media is easily accessible, it is a major resource for patients and therefore can strongly shape public beliefs about the syndrome. Physicians discussing TS with patients and families should be aware of the images in the popular media and the misperceptions that these representations can create. To help patients deal with the challenges surrounding TS, physicians can encourage discussion around individual patient perceptions of TS during appointments. 


\section{REFERENCES}

1. Freeman RD, Zinner SH, Muller-Vahl KR, et al. Coprophenomena in Tourette syndrome. Dev Med Child Neurol. 2009;51(3): 218-27.

2. Robertson MM. The prevalence and epidemiology of Gilles de la Tourette syndrome. Part 1: the epidemiological and prevalence studies. J Psychosom Res. 2008;65(5):461-72.

3. Pappert EJ, Goetz CG, Louis ED, Blasucci L, Leurgans S. Objective assessments of longitudinal outcome in Gilles de la Tourette's syndrome. Neurology. 2003;61(7):936-40.

4. Comings DE, Comings BG. Tourette syndrome: clinical and psychological aspects of 250 cases. Am J Hum Genet. 1985;37 (3):435-50.

5. Dedmon R. Tourette syndrome in children: knowledge and services. Health Soc Work. 1990;15(2):107-15.

6. Pauls DL, Towbin KE, Leckman JF, Zahner GE, Cohen DJ. Gilles de la Tourette's syndrome and obsessive-compulsive disorder. Evidence supporting a genetic relationship. Arch Gen Psychiat. 1986;43(12):1180-2.

7. Eapen V, Crncec R. Tourette syndrome in children and adolescents: special considerations. J Psychosom Res. 2009;67(6):525-32.

8. Boudjouk PJ, Woods DW, Miltenberger RG, Long ES. Negative peer evaluation in adolescents: effects of tic disorders and trichotillomania. Child Fam Behav Ther. 2000;22(1):17-28.

9. Stokes A, Bawden HN, Camfield PR, Backman JE, Dooley JM. Peer problems in Tourette's disorder. Pediatrics. 1991;87(6): 936-42.

10. Leckman JF, Zhang H, Vitale A, et al. Course of tic severity in Tourette syndrome: the first two decades. Pediatrics. 1998;102(1 Pt 1):14-19.

11. Baxendale S. Epilepsy at the movies: possession to presidential assassination. Lancet Neurol. 2003;2:764-70.

12. Moeller AD, Moeller JJ, Rahey SR, Sadler RM. Depiction of seizure first aid management in medical television dramas. Can J Neurol Sci. 2011;38:723-7.

13. Widjdicks EFM, Widjdicks CA. The portrayal of coma in contemporary motion pictures. Neurology. 2006;66:1300-3.

14. Mosberg WH Jr. Trauma, television, movies, and misinformation. Neurosurgery. 1981;8:756-8.

15. Corbin JM, Strauss A. Grounded theory research: procedures, canons, and evaluative criteria. Qualitative Sociol. 1990;13(1): 2-21.

16. Stone M, Parker T. South Park. USA: Comedy Central/ Braniff/ Comedy Partners; Season 11, Episode 8, 1997.

17. Shergold A. Dirty Filthy Love. UK: Granada Television; 2004.

18. Morrow R. Maze. USA: Bits and Pieces Picture Co./Carlyle Productions/Cypress Films/Goldheart Pictures/KBK Entertainment/Regent Entertainment/Starz! Encore Entertainment; 2000.

19. Kelley D. The Practice. USA: David E. Kelley Productions/ Daydreamers Entertain Inc./Decode Entertainment/20th Century Fox Television; Season 2, Episode 14, 1998.

20. Winick G. The Tic Code. USA: Gun for Hire Films/Jazz Films Inc.; 1999.
21. Zinner SH, Mink JW. Movement disorders 1: tics and stereotypes. Pediatr Rev. 2010;31;223-33.

22. Goldenberg JN, Brown SB, Weiner WJ. Coprolalia in younger patients with Gilles de la Tourette syndrome. Mov Disord. 1994; 9(6):622-5

23. Davis KK, Davis JS, Dowler L. In motion, out of place: the public space(s) of Tourette Syndrome. Soc Sci Med. 2004;59(1): 103-12.

24. Elliot A. Harvie Krumpet. Australia: Melodrama Pictures/ Australian Film Commission/ SBS Independent/ Film Victoria; 2003.

25. Werner P. Front of the Class. USA: Hallmark Hall of Fame Productions/ McGee Street Productions; 2008.

26. Mitchell M. Deuce Bigalow: Male Gigalo. USA: Happy Madison Productions/Out of the Blue Entertainment/Touchstone Pictures; 1999.

27. Groening M. The Simpsons. USA: Gracie Films/ 20th Century Fox Television; Season 4, Episode 7, 1989.

28. Mylod M. The Big White.USA: Ascendant Pictures/Capitol Films/Film \& Entertainment VIP Medienfonds $2 \mathrm{GmbH} \&$ Co. KG/Rising Star; 2005.

29. Kelley D. Ally McBeal. USA: 20th Century Fox Television/ David E. Kelley Productions; Season 4, Episode 9, 1998.

30. Hampton B. 7th Heaven. USA: Spelling Television; Season 4, Episode 14, 1998.

31. Bochco S, Fisher TL. L.A. Law, USA: 20th Century Fox Television; Season 4, Episode 9, 1986.

32. Dunsky E, Wallem L, Brixius L. Nurse Jackie. USA: Showtime Networks/ Lionsgate Television/ Jackson Group Entertainment/ Madison Grain Elevator/ De Long Lumber/ Caryn Mandabach Productions; Season 2, Episode 9, 2010.

33. Masius J. Touched By An Angel. USA: CBS Productions/ Caroline Productions/ Moon Water Productions; Season 7, Episode 10, 1998.

34. Marshall P. Jumping Jack Flash. USA: Lawrence Gordon Productions/Silver Pictures/Twentieth Century Fox Film Corporation; 1986.

35. Webb M. 500 Days of Summer. USA: Fox Searchlight Pictures/ Watermark/ Sneak Preview Entertainment; 2009.

36. Dobkin D. Wedding Crashers. USA: New Line Cinema/Tapestry Films/Avery Pix; 2005.

37. Coraci F. The Wedding Singer. USA: Juno Pix/ New Line Cinema/ Rober Simonds Productions; 1998.

38. Barnz D. Phoebe In Wonderland. USA: Silverwood Films; 2009.

39. Elstner K, Selai CE, Trimble MR, Robertson MM. Quality of life (qol) of patients with Gilles de la Tourette's Syndrome. Acta Psychiat Scand. 2001;103(1):52-9.

40. Altman G, Staley JD, Wener P. Children with Tourette Disorder: a follow-up study in adulthood. J Nerv Ment Dis. 2009;197(5): 305-10.

41. Diem SJ, Lantos, JD, Tulsky JA. Cardiopulmonary resuscitation on television. N Engl J Med. 1996;334:1578-82. 
Appendix: List of movies, television programs and shorts retrieved. Programs viewed as part of the study are represented in italics.

Movies
500 Days of Summer
Boondocks Saints
What about Bob
Niagara, Niagara
The Tic Code
The Big White
Maze
Crank 2
How to lose a guy in 10 days
Jimmy Zip
Deuce Bigalow: Male Gigolo
Bitch Slap
Phoebe in Wonderland
Into It
Matchstick Men
Not Another Teen Movie
Jumping Jack Flash
Wedding Singer
Wedding Crashers
Son of Sunshine
Vince Will Meer
Passing Stones
Passe-Passe (Off and Running)
Schism
Utanfor din dorr
Menaces - exclude
Garmento - exclude
Post Modern America -
exclude
Up Close - exclude
John's Arm: Armegeddon
Tic
Torrid House
Torried Without a Cause
The West Wing
Outside Your Door
The Green Door
Wish You Were Dead

Educational Videos

Psychology of Human

Behaviour

Tics and Related Disorders

Treating Tourette's and Other

Mental Illness

The Compulsive Mind:

Tourette's Syndrome/OCD

\section{Documentary}

Twitch and Shout

Direct Order

Shane: Tourette's Syndrome

Tics and Tourette's Syndrome Inside Tourette Syndrome

Family Victim

Shadows and Illuminations

Afflictions: Culture and Mental

Illness in Indonesia

The Bird Dancer

Movements and Madness: Part

1- Gusti-Ayu

Mokumentary

The Jenkins County 5th Annual Bumper Sticker Contest

TV Movies

Dirty Filthy Love

Front of the Class

Threads - excluded after

watching bc no TS

Trots

\section{Short}

Harvie Krumpet

Goofballs

How Tourette's Saved My Life James Brown Tourette's

Syndrome

\section{TV Series}

South Park- Le Petit Tourette (Season 11, Episode 8)

Curb Your Enthusiasm - The Grand Opening (Season 3, Episode 10)

The Simpsons- Marge Gets a job (Season 4, Episode 7)

NewsRadio - The Song Remains the Same (Season 2, Episode 21)

Quincy M.E. - Seldom Silent, Never Heard (Season 6, Episode 14)

L.A. Law-Noah's Bark (Season 4, Episode 9)

7th Heaven- Words (Season 4, Episode14)

Touched by an Angel - Angel on my Tree (Season 7, Episode 10) Ally McBeal - Reasons to Believe (Season 4, Episode 9)

Dexter-Easy as Pie (Season 3, Episode 7)

Being Human- I Loathe You for Sentimental Reasons (Season 2, Episode 4)

Snuff Box - The Wedding (Season 1, Episode 6)

Episodes - Untitled (Season 1, Episode 2)

Nurse Jackie - P.O. Box (Season 2, Episode 9)

The Practice - The Pursuit of Dignity (Season 2, episode 14)

The Fast Show - Recording Engineer (Season 3, Episode 6) Exclude not about TS

St. Elsewhere - Up and Down (Season 5, Episode 7)

Shameless - Tomorrow People (Season 1, Episode 5)

Malcolm in the Middle - Hal Sleepwalks (Season 6, Episode 7)

TV Fun House - Cavemen Day (Season 1, Episode 5)

L.A. Law - God Rest Ye Murray Gentleman (Season 5, Episode 8)

\section{TV Documentary}

Q.E.D. - John's Not Mad

Teenage Tourette Camp

The Boy Can't Help It

I Have Tourette's but Tourette's doesn't have me

Tourette de France

The Tourette's Guy

Tourette's

Tourette's: I Swear I Cannot Help It

Tourette's Uncovered

ABC News: Growing up with Tourette's Syndrome

20/20: A Revealing Intimate Look at Children with Tourette's

Syndrome 